\title{
Possibilities of using of selected acaricides and their mixtures in controlling of spider mites (Tetranychus urticae Koch) in sugar beet - laboratory conditions
}

\section{Możliwości wykorzystania akarycydów oraz ich mieszanin do zwalczania przędziorka chmielowca (Tetranychus urticae Koch) w uprawach buraka cukrowego - badania laboratoryjne}

\author{
Magdalena Jakubowska ${ }^{1}$, Żaneta Fiedler ${ }^{1}$, Jan Bocianowski ${ }^{2}$
}

\begin{abstract}
Summary
The two-spotted spider mite (Tetranychus urticae Koch) is a very important pest of sugar beet in Poland. The pest feeds mainly on the leaves by piercing the epidermis and extracting sap that results in yellowing and browning of leaves, and early drying and leaf falling. A heavily infested plantation will provide lower yield with reduced quality of sugar beet roots. The pest easily spreads on plantations of sugar beet. The control of $T$. urticae is very difficult due to the lack of registered products. The aim of the laboratory experiments carried out in 2013-2015 was to evaluate the usefulness of insecticides representing various chemical groups in controlling of spider mite in sugar beet. The following acaricides were evaluated: Magus 200 SC, Karate Zeon 050 CS, Envidor 240 SC, a mixture of Ortus 05 SC + Nissorun 050 EC and Vertimec 018 EC. The products Vertimec 018 EC and Envidor 240 SC showed high effectiveness in reducing the number of spider mite causing 95\% mortality of the pest in 2013 and 2015.
\end{abstract}

Key words: spider mite; sugar beet; efficiency of acaricides

\section{Streszczenie}

Przędziorek chmielowiec (Tetranychus urticae Koch) jest bardzo groźnym szkodnikiem buraka cukrowego. Szkodnik ten żeruje głównie na liściach, wysysając soki z epidermy, powodując żółcenie i brązowienie liści, wczesne ich zamieranie i opadanie. Przyczynia się do znacznego spadku wielkości i jakości plonu korzeni buraka cukrowego. Przędziorki bardzo łatwo rozprzestrzeniają się na plantacjach buraka cukrowego. Zwalczanie tego szkodnika jest bardzo trudne, gdyż w Polsce brak jest zarejestrowanych preparatów do zwalczania przędziorków w uprawach buraka cukrowego. Celem przeprowadzonych w latach 2013-2015 badań laboratoryjnych było określenie skuteczności insektycydów z różnych grup chemicznych w ochronie buraka cukrowego przed przędziorkiem chmielowcem. Przedmiotem badań były następujące akarycydy: Magus 200 SC, Karate Zeon 050 CS, Envidor 240 SC, mieszanina Ortus 05 SC + Nissorun 050 EC oraz Vertimec 018 EC. W warunkach laboratoryjnych, gdzie testowano różne akarycydy, wysoką efektywność w redukowaniu liczebności przędziorka chmielowca wykazały preparaty: Vertimec 018 EC oraz Envidor 240 SC. Powodowały około $95 \%$ śmiertelności szkodnika w roku 2013 i 2015.

Słowa kluczowe: przędziorek chmielowiec; burak cukrowy; efektywność akarycydów

\footnotetext{
${ }^{1}$ Instytut Ochrony Roślin - Państwowy Instytut Badawczy

Zakład Metod Prognozowania Agrofagów i Ekonomiki Ochrony Roślin

Władysława Węgorka 20, 60-318 Poznań

${ }^{2}$ Uniwersytet Przyrodniczy w Poznaniu

Wojska Polskiego 28, 60-637 Poznań

*corresponding author: M.Jakubowska@iorpib.poznan.pl
} 


\section{Wstęp / Introduction}

Przędziorek chmielowiec (Tetranychus urticae Koch) jest polifagiem i bardzo groźnym szkodnikiem wielu upraw. Atakuje ponad 200 gatunków roślin uprawnych, warzywnych, sadowniczych i ozdobnych, między innymi truskawki, ziemniaki, czy buraki cukrowe (Prokopy i wsp. 1990; Naher i wsp. 2006; Adel A. Abou El-Ela 2014). W ostatnich latach był bardzo licznie odnotowywanym szkodnikiem na plantacjach buraka cukrowego w Polsce, na których występował w różnym nasileniu, ale praktycznie na wszystkich uprawianych odmianach buraka (Fiedler i wsp. 2013; Jakubowska 2014; Jakubowska i Fiedler 2014; Fiedler i Jakubowska 2015; Jakubowska i Bandyk 2015; Ulatowska i wsp. 2015).

W warunkach klimatycznych Polski liczba pokoleń przędziorka chmielowca $\mathrm{w}$ sezonie wegetacyjnym może wynosić od 4 do 6 . W sprzyjających temperaturach $\left(25-30^{\circ} \mathrm{C}\right)$, co ma często miejsce późną wiosną i latem, czas rozwoju jednego pokolenia skraca się do 10 , a nawet 8 dni.

Objawy uszkodzeń powodowanych przez przędziorka chmielowca początkowo obserwuje się na brzegach pól, z czasem występują placowo na całej powierzchni uprawy. Żerowanie roztoczy widoczne jest po obu stronach blaszki liściowej. $\mathrm{Na}$ dolnej stronie pojawia się $\mathrm{w}$ postaci delikatnego oprzędu (pajęczynki) z różnymi stadiami rozwojowymi przędziorków. Na górnej stronie blaszki liściowej, w wyniku intensywnego żerowania szkodników, pojawiają się drobne, jasne plamki tworzące tzw. mozaikę. Bardzo często takie objawy żerowania przędziorka są bagatelizowane i mylone $\mathrm{z}$ objawami powodowanymi przez wirusy, nicienie lub suszę.

Konsekwencją licznego występowania przędziorka chmielowca na plantacjach buraka cukrowego jest zakłócenie fotosyntezy, ograniczenie ilości substancji pokarmowych, zahamowanie wzrostu i rozwoju roślin oraz obniżenie jakości cukru występującego w korzeniach (Jakubowska 2014). Przy wystąpieniu optymalnych warunków do rozwoju szkodnika, czyli wysokich temperaturach i braku opadów, w wyniku żerowania przędziorka chmielowca na plantacjach buraka może wystąpić znaczne obniżenie plonu. Spadek plonu korzeni może wynosić od 20 do 50\% (Legrand i Wauters 1996), a zawartość cukru w korzeniach może ulec zmniejszeniu nawet o 2\% (Legrand i wsp. 2000).

Zwalczanie tej grupy szkodników jest bardzo trudne, gdyż w związku z występowaniem kilku pokoleń w ciągu roku, obserwuje się zjawisko szybkiego nabywania odporności przez przędziorka na środki chemiczne. W praktyce ochrony roślin coraz większe zastosowanie znajdują różne czynniki biologiczne, w tym akarifagi, środki biotechniczne, czy inne oparte na naturalnych substancjach (Van Leenwen i wsp. 2010; Niu i wsp. 2014; Martin i wsp. 2015).

Obecnie nie ma żadnych zarejestrowanych akarycydów do zwalczania przędziorka chmielowca w uprawach buraka cukrowego. Od roku 2013 Instytut Ochrony Roślin - Państwowy Instytut Badawczy (IOR - PIB) wraz z koncernem Pfeifer \& Langen prowadzi doświadczenia nad skutecznością wybranych preparatów roztoczo- bójczych w walce $\mathrm{z}$ tym szkodnikiem w uprawach buraka cukrowego.

Celem przedstawionych badań laboratoryjnych była ocena skuteczności sześciu wybranych akarycydów do zwalczania przędziorka chmielowca w buraku cukrowym.

\section{Materiały i metody / Materials and methods}

Doświadczenia przeprowadzono w warunkach laboratoryjnych w latach 2013-2015, na liściach buraka cukrowego, odmiany Janosik, pobranych z pól doświadczalnych Polowej Stacji Doświadczalnej IOR - PIB w Winnej Górze. Materiał biologiczny pozyskiwano z opanowanych przez przędziorka chmielowca plantacji buraka cukrowego. Analizę skuteczności działania wybranych akarycydów wykonywano w warunkach laboratoryjnych, na płytkach Petriego. Do testów nad przeżywalnością przędziorka chmielowca wybrano dwa zarejestrowane akarycydy z grupy METI: Magus 200 SC i Ortus 05 SC; jeden produkt $\mathrm{z}$ grupy makrocyklicznych laktonów - Vertimec 018 EC; jeden z grupy tiazolidyn - Nissorun 050 EC; jeden zarejestrowany akarycyd $\mathrm{z}$ grupy kwasów tetronowych - Envidor 240 SC oraz pyretroid - Karate Zeon $050 \mathrm{SC}$.

Ustalono następujące warianty doświadczalne:

1. Magus 200 SC (substancja czynna - s. cz. fenazachina) $\mathrm{w}$ dawce $0,05 \%$, preparat $\mathrm{z}$ grupy chinazolin;

2. Vertimec 018 EC (s. cz. abamektyna) w dawce $0,05 \%$, preparat $\mathrm{z}$ grupy makrocyklicznych laktonów;

3. mieszanina Ortus $05 \mathrm{SC}$ (s. cz. fenpiroksymat) $\mathrm{W}$ dawce $0,5 \mathrm{l} / \mathrm{ha}$, preparat $\mathrm{z}$ grupy fenoksypirazoli z Nissorun 050 EC (s. cz. heksytiazoks) w dawce $0,75 \mathrm{l} / \mathrm{ha}$, preparat $\mathrm{z}$ grupy tiazolidyn;

4. Karate Zeon 050 SC (s. cz. lambda-cyhalotryna) $\mathrm{w}$ dawce $0,2 \mathrm{l} / \mathrm{ha}$, preparat $\mathrm{z}$ grupy pyretroidów;

5. Envidor $240 \mathrm{SC}$ (s. cz. spirodiklofen) w dawce $0,05 \%$, preparat z grupy kwasów tetronowych;

6. Kontrola - liście opryskiwane tylko wodą destylowaną.

Testy wykonano na liściach buraka cukrowego umieszczonych w specjalnie przygotowanych szalkach Petriego z nawilżoną wodą bibułą filtracyjną. Na tak przygotowane liście nanoszono po 10 osobników dorosłych przędziorka chmielowca. Każdy wariant (preparat) testowano w pięciu powtórzeniach (50 dorosłych osobników). Opryskiwanie preparatami liści $\mathrm{z}$ przędziorkami przeprowadzono za pomocą rozpylaczy laboratoryjnych. Dawka na hektar przeliczana była na jeden litr wody, z którego pobierano $2 \mathrm{ml}$ roztworu. Po aplikacji preparatami, płytki Petriego umieszczano $\mathrm{w}$ komorze klimatycznej $\left(25^{\circ} \mathrm{C}, 16 \mathrm{~L}: 8 \mathrm{D}\right.$ oraz $65 \%$ wilgotność względna). Obserwacje nad przeżywalnością osobników przędziorka chmielowca oceniano po 48 godzinach oraz w piątym i siódmym dniu po zabiegu opryskiwania, licząc żywe i martwe osobniki szkodnika. Zgodność rozkładu empirycznego obserwowanych cech $\mathrm{z}$ rozkładem normalnym testowano za pomocą testu normalności Shapiro i Wilka (1965). Dwuczynnikowa analiza wariancji (ANOVA) została przepro- 
wadzona w celu weryfikacji hipotez zerowych o braku wpływu lat i kombinacji preparatów oraz hipotezy o braku interakcji lata $\times$ kombinacje preparatów na wartości obserwowanych cech. Oszacowano wartości średnie i odchylenia standardowe. Obliczono wartości NIR - Tukeya, na poziomie istotności $\alpha<0,001$, w celu wykazania istotnych różnic pomiędzy wariantami.

Współzależność pomiędzy liczebnością żywych osobników roztoczy w poszczególnych dniach po zabiegu a liczbą martwych osobników oceniano na podstawie odpowiednich współczynników korelacji prostej Pearsona. Wszystkie obliczenia w zakresie analizy statystycznej wykonano korzystając $\mathrm{z}$ pakietu statystycznego Gen Stat 17.

\section{Wyniki i dyskusja / Results and discussion}

Od kilku lat rolnicy, głównie w rejonach Kujaw i Wielkopolski obserwują problem z przędziorkiem chmielowcem w uprawach buraka cukrowego. Rok 2014 był rokiem, w którym obserwowano bardzo duże nasilenie występowania tego szkodnika. Związane to było ze sprzyjającymi wysokimi temperaturami latem oraz brakiem opadów. Wyniki przeprowadzonej analizy wariancji wskazały na istotne statystycznie zróżnicowanie śmiertelności osobników przędziorka chmielowca w poszczególnych latach prowadzenia badań w zależności od terminu obserwacji, jak i kombinacji użytych preparatów (tab. 1). Interakcja pomiędzy kombinacjami zastosowanych akarycydów a latami, w których zostały przeprowadzone doświadczenia laboratoryjne miała również istotny statystycznie wpływ na liczebność żywych i martwych osobników przędziorka chmielowca w zależności od terminu obserwacji. Średnio największą śmiertelność osobników $\mathrm{z}$ tego gatunku obserwowano po zastosowaniu abamektyny (Vertimec 018 EC) we wszystkich latach badań oraz po zastosowaniu spirodiklofenu (Envidor $240 \mathrm{SC}$ ) w roku 2013 i 2015 (tab. 2, 4). Istotne statystycznie różnice w skuteczności działania preparatów w poszczególnych latach stwierdzono dla wszystkich obserwacji po 48 godzinach oraz po 5 i 7 dniach po zabiegu opryskiwania (tab. 1, 2, 4). W testach laboratoryjnych dobrą efektywnością charakteryzowała się kombinacja związku fenpiroksymatu (Ortus 05 SC) z heksytiazoksem (Nissorun 050 EC) w latach 2013 i 2015. Na podstawie uzyskanych wyników stwierdzono, że preparat Magus 200 SC działał na przędziorki podobnie, jak mieszanina Ortus $05 \mathrm{SC}$ z Nissorun 050 EC, przy czym jego efektywność była najlepsza po 48 godzinach od zastosowania preparatu (tab. 2, 4). Najmniejszą efektywnością wykazał się preparat Karate Zeon 050 CS należący do grupy pyretroidów. Sumaryczną liczbę osobników martwych przedstawiono $\mathrm{w}$ tabeli 4 . Eksperymentalnie stwierdzono, że populacje przędziorka były najskuteczniej zwalczane w latach 2014 i 2015. Liczebność martwych osobników przędziorka chmielowca była istotnie ujemnie skorelowana ze śmiertelnością osobników w 7. dobie po zastosowaniu zabiegu $(\mathrm{r}=-1,0)$ (tab. 3 ). W odniesieniu do prowadzonych testów świadczy to o tym, iż w 7. dniu po zastosowanym zabiegu liczebność martwych osobników roztocza była mniejsza w stosunku do ogólnej śmiertelności osobników przędziorka chmielowca w poszczególnych terminach obserwacji. Ma to znaczenie w dalszych badaniach nad efektywnością zastosowanych akarycydów w warunkach polowych.

Tabela 1. Dwuczynnikowa analiza wariancji liczebności żywych i martwych osobników przędziorka chmielowca (Tetranychus urticae Koch) w kolejnych terminach obserwacji od przeprowadzonych zabiegów zwalczania roztocza w latach 2013-2015

Table 1. The results of two-way analysis of variance of the number of living and dead mites (Tetranychus urticae Koch) in subsequent dates of observations performed $48 \mathrm{hrs}, 5$ and 7 days after the treatments in 2013-2015

\begin{tabular}{|c|c|c|c|c|}
\hline $\begin{array}{l}\text { Źródło zmienności } \\
\text { Source of variability }\end{array}$ & $\begin{array}{c}\text { Stopnie swobody } \\
\text { Number of degrees of freedom }\end{array}$ & $\begin{array}{l}\text { Suma kwadratów } \\
\text { Sum of the squares }\end{array}$ & $\begin{array}{l}\text { Średnie kwadraty } \\
\text { Medium squares }\end{array}$ & $\begin{array}{c}\text { Statystyka F-Snedecora } \\
\text { Statistic F-Snedecor's }\end{array}$ \\
\hline 1 & 2 & 3 & 4 & 5 \\
\hline \multicolumn{5}{|c|}{ Po 48 godzinach po zabiegu -48 hours after treatment } \\
\hline Rok - Year & 2 & 62,689 & $31,344 * * *$ & 12,85 \\
\hline $\begin{array}{l}\text { Kombinacje preparatów } \\
\text { Treatments }\end{array}$ & 5 & 339,822 & $67,964 * * *$ & 27,87 \\
\hline $\begin{array}{l}\text { Rok } \times \text { Kombinacje preparatów } \\
\text { Year } \times \text { Treatments }\end{array}$ & 10 & 363,711 & $36,371 * * *$ & 14,91 \\
\hline Błąd - Error & 72 & 175,600 & 2,439 & - \\
\hline \multicolumn{5}{|c|}{5 dni po zabiegu -5 days after treatment } \\
\hline $\begin{array}{l}\text { Źródło zmienności } \\
\text { Source of variability }\end{array}$ & $\begin{array}{c}\text { stopnie swobody } \\
\text { number of degrees of freedom }\end{array}$ & $\begin{array}{l}\text { suma kwadratów } \\
\text { sum of the squares }\end{array}$ & $\begin{array}{l}\text { średnie kwadraty } \\
\text { medium squares }\end{array}$ & $\begin{array}{c}\text { statystyka F-Snedecora } \\
\text { statistic F-Snedecor's }\end{array}$ \\
\hline Rok - Year & 2 & 128,356 & $64,178^{* * *}$ & 31,74 \\
\hline $\begin{array}{l}\text { Kombinacje preparatów } \\
\text { Treatments }\end{array}$ & 5 & 229,422 & $45,884 * * *$ & 22,69 \\
\hline $\begin{array}{l}\text { Rok } \times \text { Kombinacje preparatów } \\
\text { Year } \times \text { Treatments }\end{array}$ & 10 & 390,578 & $39,058^{* * *}$ & 19,31 \\
\hline Błąd - Error & 72 & 145,600 & $2,022 * * *$ & - \\
\hline
\end{tabular}




\begin{tabular}{l|c|c|c|c}
\hline \multicolumn{1}{c|}{1} & 2 & 3 & 4 & 5 \\
\hline \multicolumn{1}{c|}{$\begin{array}{c}\text { Źródło zmienności } \\
\text { Source of variability }\end{array}$} & $\begin{array}{c}\text { 7 dni po zabiegu }-7 \text { days after treatment } \\
\text { number of degrees of freedom }\end{array}$ & $\begin{array}{c}\text { suma kwadratów } \\
\text { sum of the squares }\end{array}$ & $\begin{array}{c}\text { średnie kwadraty } \\
\text { medium squares }\end{array}$ & $\begin{array}{c}\text { statystyka F-Snedecora } \\
\text { statistic F-Snedecor's }\end{array}$ \\
\hline Rok - Year & 2 & 125,489 & $62,744^{* * *}$ & 47,45 \\
\hline $\begin{array}{l}\text { Kombinacje preparatów } \\
\text { Treatments }\end{array}$ & 5 & 147,156 & $29,431^{* * *}$ & 22,26 \\
\hline $\begin{array}{l}\text { Rok } \times \text { Kombinacje preparatów } \\
\text { Year } \times \text { Treatments }\end{array}$ & 10 & 390,111 & $39,011^{* * *}$ & 29,50 \\
\hline Błąd - Error & 72 & 95,200 & 1,322 & \\
\hline
\end{tabular}

$* * * \mathrm{p}<0,001$

Tabela 2. Średnia liczebność żywych i martwych osobników przędziorka chmielowca (Tetranychus urticae Koch) w kolejnych terminach obserwacji od przeprowadzonych zabiegów zwalczania roztocza w latach 2013-2015

Table 2. The mean values of live and dead mites (Tetranychus urticae Koch) in subsequent dates of observations performed 48 hrs, 5 and 7 days after the treatments in 2013-2015

\begin{tabular}{|c|c|c|c|c|}
\hline & $\begin{array}{l}\text { Liczebność żywych } \\
\text { osobników T. urticae } \\
\text { po } 48 \text { godzinach } \\
\text { No. of live individuals } \\
\text { of } T \text {. urticae after } 48 \mathrm{hrs}\end{array}$ & $\begin{array}{c}\text { Liczebność żywych } \\
\text { osobników T. urticae } \\
\text { po } 5 \text { dniach } \\
\text { No. of live individuals } \\
\text { of } T \text {. urticae after } 5 \text { days }\end{array}$ & $\begin{array}{c}\text { Liczebność żywych } \\
\text { osobników T. urticae } \\
\text { po } 7 \text { dniach } \\
\text { No. of live individuals } \\
\text { of T. urticae after } 7 \text { days }\end{array}$ & $\begin{array}{c}\text { Liczba osobników } \\
\text { martwych } \\
\text { No. of dead individuals }\end{array}$ \\
\hline \multicolumn{5}{|c|}{ Rok-Year } \\
\hline 2013 & $3,00 \mathrm{c}$ & $1,93 \mathrm{~b}$ & $1,80 \mathrm{~b}$ & $8,20 \mathrm{~b}$ \\
\hline 2014 & $5,03 \mathrm{a}$ & $4,07 \mathrm{a}$ & $2,90 \mathrm{a}$ & $7,10 \mathrm{c}$ \\
\hline 2015 & $3,83 \mathrm{~b}$ & $1,27 \mathrm{~b}$ & $0,03 \mathrm{c}$ & $9,97 \mathrm{a}$ \\
\hline $\begin{array}{l}\operatorname{NIR}(0,05) \\
\operatorname{LSD}(0.05)\end{array}$ & 0,804 & 0,732 & 0,592 & 0,592 \\
\hline \multicolumn{5}{|c|}{ Kombinacja - Treatments } \\
\hline Magus $200 \mathrm{SC}$ & $4,40 \mathrm{~b}$ & $3,20 \mathrm{~b}$ & $2,87 \mathrm{a}$ & $7,13 \mathrm{c}$ \\
\hline Vertimec $018 \mathrm{EC}$ & $1,40 \mathrm{c}$ & $0,27 \mathrm{~d}$ & $0,00 \mathrm{c}$ & $10,00 \mathrm{a}$ \\
\hline $\begin{array}{l}\text { Ortus } 05 \mathrm{SC} \\
+ \text { Nissorun } 050 \mathrm{EC}\end{array}$ & $4,40 \mathrm{~b}$ & $1,60 \mathrm{c}$ & $1,40 \mathrm{~b}$ & $8,60 \mathrm{~b}$ \\
\hline $\begin{array}{l}\text { Karate Zeon } \\
050 \mathrm{CS}\end{array}$ & $5,13 \mathrm{~b}$ & $3,27 \mathrm{~b}$ & $1,73 \mathrm{~b}$ & $8,27 \mathrm{~b}$ \\
\hline Envidor $240 \mathrm{SC}$ & $1,53 \mathrm{c}$ & $1,13 \mathrm{~cd}$ & $0,07 \mathrm{c}$ & $9,93 \mathrm{a}$ \\
\hline Kontrola - Control & $6,87 \mathrm{a}$ & 5,07 a & $3,40 \mathrm{a}$ & $6,60 \mathrm{c}$ \\
\hline $\begin{array}{l}\operatorname{NIR}(0,05) \\
\operatorname{LSD}(0.05)\end{array}$ & 1,137 & 1,035 & 0,837 & 0,837 \\
\hline
\end{tabular}

Wartości w kolumnach oznaczone tą samą literą nie różnią się istotnie statystycznie

The values in the columns marked with the same letter do not differ significantly

NIR $(0,05)$ - istotności różnic pomiędzy średnimi grupowymi w układzie analizy wariancji

LSD $(0.05)$ - the significance of differences between the means of group in a way analysis of variance

W Polsce dobre wyniki w zwalczaniu przędziorka chmielowca $\mathrm{w}$ truskawkach uzyskano po zastosowaniu abamektyny - preparatu Vertimec 018 EC (Labanowska 1992), spirodiklofenu - preparatu Envidor 240 SC, fenazachinu - preparatu Magus 200 SC oraz w uprawach roślin ozdobnych (róże pod osłonami) (Łabanowska 2006). Podobne wyniki skuteczności zaobserwowano w przypadku preparatu insektycydowego Ortus 05 SC zarejestrowanego w ogórku, pomidorze, papryce, cukinii i oberżynie do zwalczania przędziorków, we wszystkich tych upra- wach skutecznie redukował on liczebność populacji tego roztocza (Łabanowska 2007, 2014).

Aktualnie nie ma preparatów insektycydowych do zwalczania przędziorka chmielowca dopuszczonych do obrotu i stosowania w uprawach buraka cukrowego. Przedstawione $\mathrm{w}$ pracy wyniki doświadczeń przeprowadzonych $\mathrm{w}$ warunkach laboratoryjnych na liściach buraka cukrowego pokazały możliwości zastosowania wybranych akarycydów zarejestrowanych $\mathrm{w}$ innych uprawach do zwalczania przędziorka chmielowca również na plan 
Tabela 3. Korelacja między liczebnością żywych i martwych osobników przędziorka chmielowca (Tetranychus urticae Koch) w kolejnych terminach obserwacji od przeprowadzonych zabiegów zwalczania roztocza w latach 2013-2015

Table 3. The coefficient correlation between the live and dead mites (Tetranychus urticae Koch) in subsequent dates of observations performed $48 \mathrm{hrs}, 5$ and 7 days after treatment in 2013-2015

\begin{tabular}{|c|c|c|c|c|}
\hline & $\begin{array}{c}\text { Wartość współczynnika } \\
\text { korelacji po } 48 \text { godzinach } \\
\text { od zabiegu } \\
\text { Correlation coefficient } \\
48 \text { hours after treatment }\end{array}$ & $\begin{array}{l}\text { Wartość współczynnika } \\
\text { korelacji po } 5 \text { dniach } \\
\text { od zabiegu } \\
\text { Correlation coefficient } \\
5 \text { days after treatment }\end{array}$ & $\begin{array}{l}\text { Wartość współczynnika } \\
\text { korelacji po } 7 \text { dniach } \\
\text { od zabiegu } \\
\text { Correlation coefficient } \\
7 \text { days after treatment }\end{array}$ & 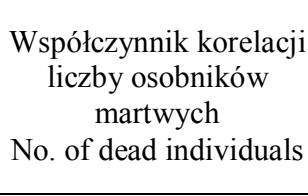 \\
\hline $\begin{array}{l}\text { Wartość współczynnika } \\
\text { korelacji } \\
\text { po } 48 \text { godzinach } \\
\text { po zabiegu } \\
\text { Correlation coefficient } \\
48 \text { hours after treatment }\end{array}$ & 1 & - & - & - \\
\hline $\begin{array}{l}\text { Wartość współczynnika } \\
\text { korelacji po } 5 \text { dniach } \\
\text { po zabiegu } \\
\text { Correlation coefficient } \\
5 \text { days after treatment }\end{array}$ & $0,8541 * * *$ & 1 & - & - \\
\hline $\begin{array}{l}\text { Wartość współczynnika } \\
\text { korelacji po } 7 \text { dniach } \\
\text { po zabiegu } \\
\text { Correlation coefficient } \\
7 \text { days after treatment }\end{array}$ & $0,7472 * * *$ & $0,8602 * * *$ & 1 & - \\
\hline $\begin{array}{l}\text { Współczynnik korelacji } \\
\text { liczby osobników } \\
\text { martwych } \\
\text { No. of dead individuals }\end{array}$ & $-0,7472 * * *$ & $-0,8602 * * *$ & $-1,000 * * *$ & 1 \\
\hline
\end{tabular}

$* * *_{-}<0,001$

Tabela 4. Średnia liczebność żywych i martwych osobników przędziorka chmielowca (Tetranychus urticae Koch) w kolejnych terminach obserwacji od przeprowadzonych zabiegów zwalczania roztocza w latach 2013-2015

Table 4. The mean values and standard deviation for the number of individuals of living and dead mites chmielowca (Tetranychus urticae Koch) in subsequent dates of observation performed 48 hours, 5 and 7 days after the treatments of selected chemical substance in 2013-2015

\begin{tabular}{|c|c|c|c|c|c|c|c|c|}
\hline $\begin{array}{l}\text { Zmienna } \\
\text { Variable }\end{array}$ & \multicolumn{2}{|c|}{$\begin{array}{l}\text { Liczebność żywych } \\
\text { osobników } T \text {. urticae } \\
\text { po } 48 \text { godzinach } \\
\text { No. of live individuals } \\
\text { of } T \text {. urticae } \\
\text { after } 48 \text { hours }\end{array}$} & \multicolumn{2}{|c|}{$\begin{array}{l}\text { Liczebność żywych } \\
\text { osobników } T \text {. urticae } \\
\text { po } 5 \text { dniach } \\
\text { No. of live individuals } \\
\text { of } T \text {. urticae } \\
\text { after } 5 \text { days }\end{array}$} & \multicolumn{2}{|c|}{$\begin{array}{c}\text { Liczebność żywych } \\
\text { osobników T. urticae } \\
\text { po } 7 \text { dniach } \\
\text { No. of live individuals } \\
\text { of T. urticae after } 7 \text { days }\end{array}$} & \multicolumn{2}{|c|}{$\begin{array}{c}\text { Liczba osobników } \\
\text { martwych }\end{array}$} \\
\hline \multicolumn{9}{|c|}{2013} \\
\hline 1 & 2 & 3 & 4 & 5 & 6 & 7 & 8 & 9 \\
\hline $\begin{array}{l}\text { Kombinacja } \\
\text { preparatów } \\
\text { Treatments }\end{array}$ & $\begin{array}{c}\text { średnia } \\
\text { mean }\end{array}$ & s.d. & $\begin{array}{c}\text { średnia } \\
\text { mean }\end{array}$ & s.d. & $\begin{array}{c}\text { średnia } \\
\text { mean }\end{array}$ & s.d. & $\begin{array}{c}\text { średnia } \\
\text { mean }\end{array}$ & s.d. \\
\hline $\begin{array}{l}\text { Magus } \\
200 \text { SC }\end{array}$ & 1,80 & 1,30 & 0,60 & 0,89 & 0,40 & 0,55 & 9,6 & 0,55 \\
\hline $\begin{array}{l}\text { Vertimec } \\
018 \text { EC }\end{array}$ & 0,40 & 0,55 & - & - & - & - & 10,0 & - \\
\hline $\begin{array}{l}\text { Ortus } \\
05 \mathrm{SC} \\
+ \text { Nissorun } \\
050 \text { EC }\end{array}$ & 2,00 & 1,00 & 0,40 & 0,55 & 0,40 & 0,55 & 9,6 & 0,55 \\
\hline $\begin{array}{l}\text { Karate Zeon } \\
050 \text { CS }\end{array}$ & 3,80 & 1,64 & 1,40 & 1,14 & 1,20 & 0,84 & 8,80 & 0,84 \\
\hline $\begin{array}{l}\text { Envidor } \\
240 \text { SC }\end{array}$ & 0,60 & 0,89 & - & - & - & - & 10,00 & - \\
\hline
\end{tabular}




\begin{tabular}{|c|c|c|c|c|c|c|c|c|}
\hline 1 & 2 & 3 & 4 & 5 & 6 & 7 & 8 & 9 \\
\hline $\begin{array}{l}\text { Kontrola } \\
\text { Control }\end{array}$ & 9,40 & 0,89 & 9,20 & 0,84 & 8,80 & 0,84 & 1,20 & 0,84 \\
\hline $\begin{array}{l}\text { Średnie } \\
\text { Averages }\end{array}$ & 3,00 & - & 1,93 & - & 1,80 & - & 8,2 & - \\
\hline \multicolumn{9}{|c|}{2014} \\
\hline $\begin{array}{l}\text { Kombinacja } \\
\text { preparatów } \\
\text { Treatments }\end{array}$ & $\begin{array}{l}\text { średnia } \\
\text { mean }\end{array}$ & s.d. & $\begin{array}{c}\text { średnia } \\
\text { mean }\end{array}$ & s.d. & $\begin{array}{l}\text { średnia } \\
\text { mean }\end{array}$ & s.d. & $\begin{array}{l}\text { średnia } \\
\text { mean }\end{array}$ & s.d. \\
\hline $\begin{array}{l}\text { Magus } \\
200 \text { SC }\end{array}$ & 9,60 & 0,89 & 8,80 & 1,09 & 8,20 & 2,05 & 1,80 & 2,05 \\
\hline $\begin{array}{l}\text { Vertimec } \\
018 \text { EC }\end{array}$ & 0,40 & 0,55 & - & - & - & - & 10,00 & - \\
\hline $\begin{array}{l}\text { Ortus } \\
05 \mathrm{SC} \\
+ \text { Nissorun } \\
050 \mathrm{EC}\end{array}$ & 7,20 & 0,84 & 3,80 & 1,48 & 3,80 & 2,59 & 6,20 & 2,59 \\
\hline $\begin{array}{l}\text { Karate Zeon } \\
050 \mathrm{CS}\end{array}$ & 7,60 & 3,36 & 7,00 & 3,67 & 3,80 & 2,77 & 6,20 & 2,77 \\
\hline $\begin{array}{l}\text { Envidor } \\
240 \mathrm{SC}\end{array}$ & 0,80 & 1,30 & 1,40 & 2,07 & 0,20 & 0,45 & 9,80 & 0,45 \\
\hline $\begin{array}{l}\text { Kontrola } \\
\text { Control }\end{array}$ & 4,60 & 2,88 & 3,40 & 1,82 & 1,40 & 1,67 & 8,60 & 1,67 \\
\hline $\begin{array}{l}\text { Średnie } \\
\text { Averages }\end{array}$ & 5,03 & - & 4,07 & - & 2,9 & - & 9,07 & - \\
\hline \multicolumn{9}{|c|}{2015} \\
\hline $\begin{array}{l}\text { Kombinacja } \\
\text { preparatów } \\
\text { Treatments }\end{array}$ & $\begin{array}{l}\text { średnia } \\
\text { mean }\end{array}$ & s.d. & $\begin{array}{c}\text { średnia } \\
\text { mean }\end{array}$ & s.d. & $\begin{array}{l}\text { średnia } \\
\text { mean }\end{array}$ & s.d. & $\begin{array}{l}\text { średnia } \\
\text { mean }\end{array}$ & s.d. \\
\hline $\begin{array}{l}\text { Magus } \\
200 \text { SC }\end{array}$ & 1,80 & 1,64 & 0,20 & 0,45 & - & - & 10,00 & - \\
\hline $\begin{array}{l}\text { Vertimec } \\
018 \text { EC }\end{array}$ & 3,40 & 1,14 & 0,80 & 0,84 & - & - & 10,00 & - \\
\hline $\begin{array}{l}\text { Ortus } \\
05 \mathrm{SC} \\
+ \text { Nissorun } \\
050 \mathrm{EC}\end{array}$ & 4,00 & 1,87 & 0,60 & 0,89 & - & - & 10,00 & - \\
\hline $\begin{array}{l}\text { Karate Zeon } \\
050 \text { CS }\end{array}$ & 4,00 & 1,87 & 1,40 & 1,14 & 0,20 & 0,45 & 9,80 & 0,45 \\
\hline $\begin{array}{l}\text { Envidor } \\
240 \mathrm{SC}\end{array}$ & 3,20 & 1,09 & 2,00 & 1,41 & - & - & 10,00 & - \\
\hline $\begin{array}{l}\text { Kontrola } \\
\text { Control }\end{array}$ & 6,60 & 1,14 & 2,60 & 1,95 & - & - & 10,00 & - \\
\hline $\begin{array}{l}\text { Średnie } \\
\text { Averages }\end{array}$ & 3,83 & - & 1,27 & - & 0,03 & - & 9,97 & - \\
\hline $\begin{array}{l}\operatorname{NIR}(0,05) \\
\operatorname{LSD}(0.05)\end{array}$ & \multicolumn{2}{|c|}{1,969} & \multicolumn{2}{|c|}{1,793} & \multicolumn{2}{|c|}{1,450} & \multicolumn{2}{|c|}{1,450} \\
\hline
\end{tabular}

s.d. - odchylenie standardowe, $\mathrm{p}<0,05$ - standard deviation, $\mathrm{p}<0.05$

tacjach buraka cukrowego. Kolejnymi etapami powinno być przetestowanie tych środków ochrony roślin w warunkach polowych i przekonanie producentów o rozszerzenie ich zastosowania w uprawach buraka cukrowego. Byłaby to korzystna sytuacja dla plantatorów, którzy od kilku lat mają poważny problem $\mathrm{z}$ przędziorkami $\mathrm{w}$ uprawach buraka cukrowego i obecnie żadnych dostępnych rozwiązań w tej kwestii.

\section{Wnioski / Conclusions}

1. Najbardziej skuteczne w redukowaniu liczebności przędziorka chmielowca na liściach buraka cukrowego okazały się preparaty biotechniczne: Vertimec 018 EC oraz Envidor 240 SC.

2. Najmniejszą efektywnością W zwalczaniu przędziorków wykazał się preparat Karate Zeon 050 CS, należący do grupy pyretroidów. 


\section{Literatura / References}

Adel A. Abou El-Ela. 2014. Efficacy of five acaricides against the two-spotted spider mite Tetranychus urticae Koch and their side effects on some natural enemies. The Journal of Basic \& Applied Zoology 67 (1): 13-18.

Fiedler Ż., Jakubowska M. 2015. Najpierw przędziorki teraz wciornastki. [First mites now thrips]. Przedsiębiorca rolny 9 (11): 64-65.

Fiedler Ż., Sosnowska D., Kaniewski R., Władyka-Przybylak M. 2013. Wykorzystanie kompozycji z olejku konopnego do ograniczania liczebności przędziorków (Tetranychidae). [Possibilities of the use of composition of the extract of hemp to reduce the number of spider mites (Tetranychidae)]. Progress in Plant Protection/Postępy w Ochronie Roślin 53 (4): 679-682.

Jakubowska M. 2014. Przędziorki - nowym zagrożeniem dla buraków? Burak cukrowy 1: 14-16.

Jakubowska M., Bandyk A. 2015. Wciornastki i przędziorki w ataku. [Thrips and spider mites attack]. Rolnicze ABC 8 (299): 16-17.

Jakubowska M., Fiedler Ż. 2014. Plantacje buraków zagrożone przez przędziorki. Ważny jest monitoring. [Beet plantations endangered by mites]. Poradnik Plantatora Buraka Cukrowego 2: 53-54.

Legrand G., Wauters A. 1996. Sugar beet field infestation by the two-spotted spider mite, Tetranychus urticae Koch (Acarida, Tetranychidae) in 1996 in Belgium and variety sensibility. AGRIS 60: 497-502.

Legrand G., Wauters A., Muchembled C., Richard-Molard M. 2000. The common yellow spidermite (Tetranychus urticae Koch) (Acari: Tetranychidae) in sugar beet in Europe: a new problem. 63. IIRB Congress, Interlaken, Switzerland, February 9-10, 2000. Comptes-Rendus des Congres de l'Institut International de Recherches Betteravieres (Belgium), Vol. 63: 245-256.

Łabanowska B. 1992. Effectiveness of the acaricides in the control of the strawberry mite - Phytonemus pallidus ssp. fragariae Zimm. Fruit Science Report 19 (3): 137-146.

Łabanowska B. 2006. Envidor 240 SC - a new acaricides and its efficacy in controlling strawberry mite (Phytonemus pallidus ssp. fragariae Zimm.) and two-spotted spider mite (Tetranychus urticae Koch) on strawberry in Poland. IOBC/WPRS Bulletin 29 (9): $115-122$.

Łabanowska B. 2007. Efektywność wybranych akarycydów nowej generacji w zwalczaniu przędziorka chmielowca (Tetranychus urticae Koch) na truskawce. [Efficacy of some new generation acaricides in the control of two-spotted spider mite (Tetranychus urticae Koch) on strawberry]. Zeszyty Naukowe Instytut Sadownictwa i Kwiaciarstwa 15: 87-92.

Łabanowska B. 2014. Ocena biologicznej skuteczności preparatu Ortus 05 SC (fenpiroksymat) w zwalczaniu roztocza truskawkowca (Phytonemus pallidus Banks.) na truskawce po zbiorze owoców. [Efficacy of Ortus 05 SC (fenpiroximate) in control of the strawberry mite (Phytonemus pallidus Banks.) on strawberry plantations after fruit harvest]. Progress in Plant Protection 54 (1): 44-50.

Martin D.E., Latheef M.A., López J.D. 2015. Evaluation of selected acaricides against twospotted spider mite (Acari: Tetranychidae) on greenhouse cotton using multispectral data. Experimental and Applied Acarology: 1-19. DOI: 10.1007/s10493-015-9903-6.

Naher N., Islam W., Haque M.M. 2006. Predation of three predators on two-spotted spider mite, (Tetranychus urticae Koch) (Acari: Tetranychidae). Journal Life Earth Science 1 (1): 1-4.

Niu Z.M., Xie P., Yu L., Bi J.L. 2014. Efficacy of selected acaricides against the two-spotted spider mite Tetranychus urticae on strawberries in greenhouse production. International Journal of Agriculture Innovations and Research 3 (1): 235-239.

Prokopy R.J., Johnso S.A., O’Brien M.T. 1990. Second-stage-integrated management of apple arthropod pests. Entomologia Experimentalis et Applicata 54 (1): 9-19.

Shapiro S.S., Wilk M.B. 1965. An analysis of variance test for normality (complete samples). Biometrika 52 (3/4): 591-611.

Ulatowska A., Górski D., Piszczek J. 2015. Ocena stanu zagrożenia plantacji buraka cukrowego przez przędziorka chmielowca (Tetranychus urticae Koch.) w województwie kujawsko-pomorskim. [Monitoring of the two-spotted spider mite (Tetranychus urticae Koch.) occurence on sugar beet crops in kuyavian-pomeranian voivodeship]. Zagadnienia Doradztwa Rolniczego 4: 125-132.

Van Leenwen T., Vontas J., Tsagkarakou A., Dermauw W., Tirry L. 2010. Acaricide resistance mechanisms in the two-spotted spider mite Tetranychus urticae and other important Acari: a review. Insect Biochemistry Molecular Biology 40 (8): 563-572. 